\title{
甲状腺濾胞癌の胸椎転移により脊髄麻痷の始まった 患者に対する積極的治療
}

東京女子医科大学内分泌疾患総合医療センター外科（主任：藤本吉秀教授）

$\begin{array}{lllll}\text { 原 } & \text { 尚 } & \text { 八 } & \text { 代 } & \text { 享 } \\ \text { 山下 } & \text { 共 } & \text { 行 } & \text { 藤 } & \text { 本吉 } \\ \text { 秀 }\end{array}$

東京女子医科大学放射線科

日下部きよ子

同 整形外科

田川宏

同 病院病理科

平山章

甲状腺滤胞癌脊椎転移により, 春㭪道圧迫症状の現われた症例に对して, 積極的に治療 を行ない，期待した効果を得た。

症例は51歳女性。18年前他院にて甲状腺左葉部分切除を受けている。数カ月前より腰 痛, 歩行困難が出現。 ${ }^{201} \mathrm{Tl}$ シンチにて甲状腺慮胞癌胸椎転移と診断され入院. 春䯣圧迫 症状の進行が急なため, 先ず椎弓切除を施行. 麻疸は改善し, 歩行可能となり, 甲状腺 全摘施行, 甲状腺には滤胞癌と腺腫様甲状腺腫が認められた. 引き続き ${ }^{131} \mathrm{I}$ 大量投与によ り転移腫湟は縮小した， 2 年後の今日, 患者は尚生存中であり, 転移腫湯は少し増大傾 向にある.

甲状腺分化癌は骨転移例においても，他の悪性稙瘍の骨転移例に比へ，比較的長い生 存期間が期待できる。このため, 脊椎骨転移による替髄圧迫症状が生じた場合にも，椎 弓切除等の除圧を試みることは，効果も期待でき，意義があると思われる.

索引用語：甲状腺濾胞癌, 春椎骨転移, 春䯣麻疸

はじめに

甲状腺濾胞癌は血行性転移を起こして臨床上問題と なることがしばしばある。沗椎骨転移を生じれば，脊 髄王迫症状を起こし, その場合には早急な対処が必要 である。

我々の経験した症例では，胸椎転移によって生じた

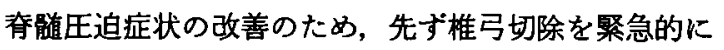
行ない, 神経学的徵候の改善を得た後に甲状腺全摘， それに引き続き ${ }^{131} I$ 治療を行ない，良好な経過をとっ たので報告する。

\section{I. 症例報告}

症例：51歳, 女性.
主訴：頸部重瘤, 腰痛および下肢しびれ感。

既往歴：特記すべきことはない。

家族歴：父胃癌，母腃溢血，姝甲状腺腫大。

現病歴：約30年前より左頝部連瘤を自覚していた。 昭和 41 年他院にて甲状腺左葉結節の摘除を受けた. 手 術直後に右葉にも小腫瘤を触れ，徐々に増大してきた。 昭和58年より腰痛が出現し, 昭和59年 2 月歩行困難が 出現した. 同年 4 月上り下䁌しびれ感が生し，5月に なって歩行不能となり，5月7日に甲状腺癌とその血 行性転移の疑いで入院した。

入院時所見：体温 $36.1^{\circ} \mathrm{C}$, 脈拍 $72 /$ 分, 血压146/102. 意識清明であるが, 歩行不能で寝たきりの状態である.

甲状腺右葉に $4.5 \times 4 \mathrm{~cm}$ と径 $2 \mathrm{~cm}$ の 2 個の可動制限 のある表面平滑な腫瘤を触知する。左葉にも径 $1.5 \mathrm{~cm}$ 

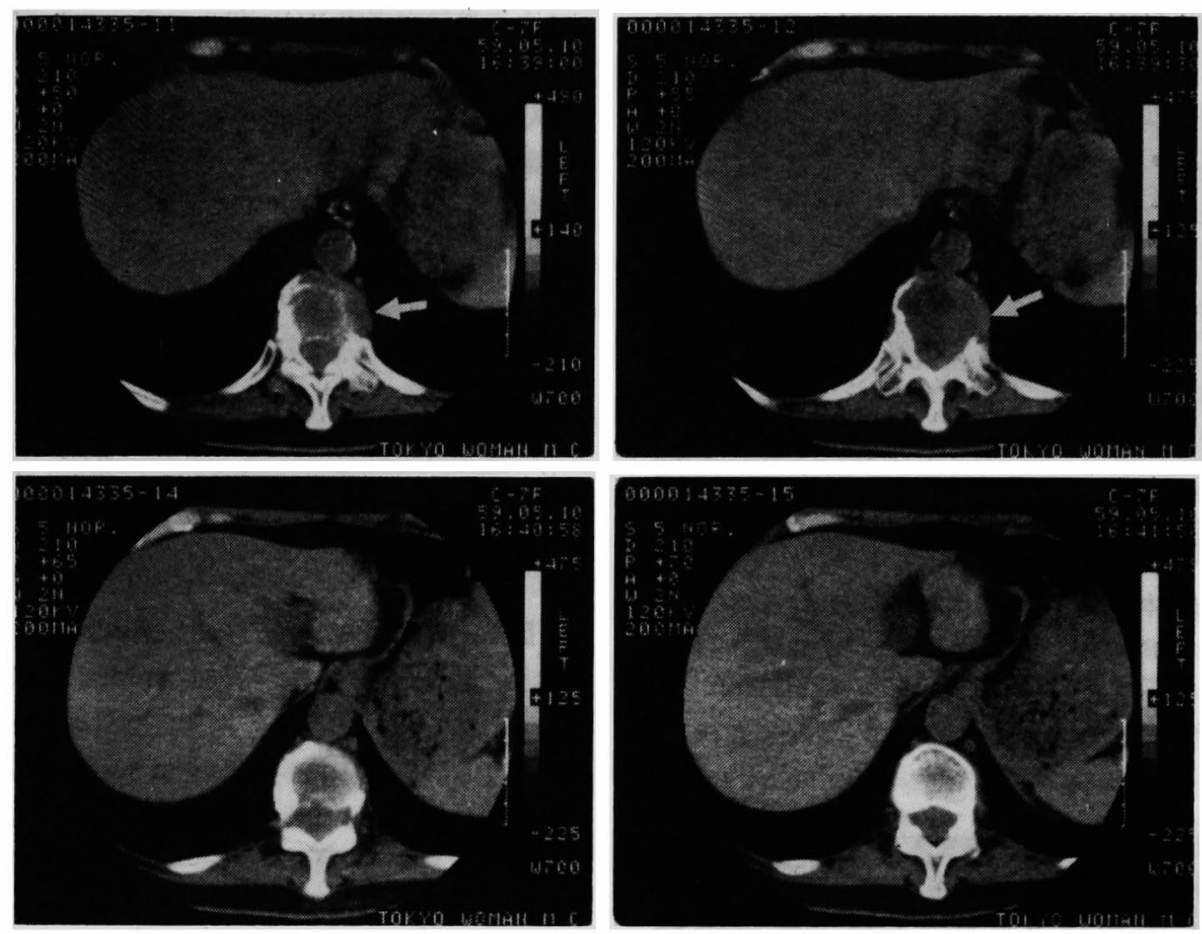

図 1 胸椎 CT：椎体骨の転移巣（矢印）において腫瘍が脊䯣を王迫している.

の可動性のよい腫瘤を触知する．頸部リンパ節は触知 しない. 両下肢に運動能と知覚の低下があり, ankle clonus, Babinski 徵候が両側に陽性であった。

検查成績：血算異常なく，血清アルブミン $4.0 \mathrm{~g} / \mathrm{dl}$, Ca $10.6 \mathrm{mg} / \mathrm{dl}, \mathrm{P} 3.7 \mathrm{mg} / \mathrm{dl}$, LDH $152 \mathrm{mU} / \mathrm{ml}$, ALP $5.8 \mathrm{KA}$ 単位. 甲状腺機能検査では, 血清 $\mathrm{T}_{3} 118 \mathrm{ng} / \mathrm{dl}$, $\mathrm{T}_{4} 7.2 \mu \mathrm{g} / \mathrm{dl}$, free $\mathrm{T}_{4} 1.52 \mathrm{ng} / \mathrm{dl}$, TSH $1.1 \mu \mathrm{U} / \mathrm{ml}$, 血 清サイロクロブリン $5,550 \mathrm{ng} / \mathrm{ml}$ (正常 35 以下), サイロ グロブリン自己抗体陰性, マイクロゾーム抗体陰性.

尿検查で蛋白・糖ともに陰性.

診断：頸部軟線撮影にて，甲状腺腫瘤に一致して， 粗大不整形の石灰沈着陰影が認められた。頝部超音波 検査では，境界明瞭な腫瘤と境界不明瞭な腫瘤が，両 葉・峡部にわたって多数認められた，触診所見，軟 $\mathrm{X}$ 線撮影，超音波所見を合わせ考え，甲状腺濾胞癌か強 く簯われた。

${ }^{201} \mathrm{Tl}$ シングラムにて甲状腺および胸椎に強い取り 込みが見られ, ${ }^{99 m}$ Tc MDP 骨シンチグラムに扎いて第 11胸椎に異常な取り込みが認められた。この部位の CTスキャンにて，椎体骨に生じた転移腫崵が脊鹃を 王迫しているのが認められた（図 1).

以上より甲状腺滤胞癌の胸椎転移による春髄圧迫の
ための下半身麻痷と診断した。

入院啳の経過：患者は昭和59年 5 月 7 日に甲状腺全 摘の目的にて入院したが，入院後 2 日目より排尿困難 が出現し，下肢筋力の低下る見られたそここで神経学 的徵候の改善をはかることがすず急務と判断し， 5 月 10 日当院整形外科入転科, 翌 5 月11日に第11胸椎々弓 切除およびハリントンロッド法による脊椎固定術が行 なわれた. 手術時腫瘍部の一部が生検され, 病理組織 検査にて滤胞構造を認めたため, 甲状腺癌の転移であ ることが確認された。

術後経過は良好で, 25 日目の 6 月 5 日に当科へ転科 した。転科時杖にて歩行可能であり，異常反射はすぺ て消失していた。

甲状腺手術：6月11日甲状腺全摘を施行. 以前に手 術を行っているため, 左側に瘜着が高度に見られたが， 左葉の甲状腺組織は十分にまた残存していた。甲状腺 には両葉に数個の結節が多発していた，上皮小体は 4 腺とも血行をつけて温存し, 甲状腺全摘を行なった。 肉眼的にリンパ節の連大は認めず，郭清は行なわな かった.

摘除甲状腺割面の肉眼所見: 肉眼的に被膜浸潤が認 められ, 明らかに癁胞癌と見られる径 $4.5 \mathrm{~cm}$ の腫瘤が 


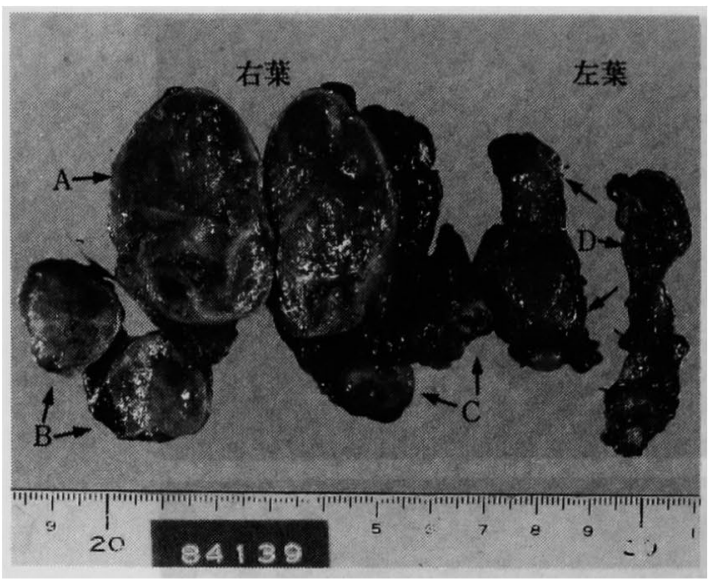

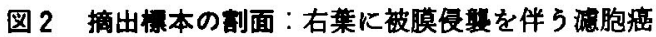
(A) と，それと類似の割面所見をるつ小尰瘤が2 個 (B，C), 他に左葉に腺腫様甲状腺腫の結節が散在し て認められる(D).

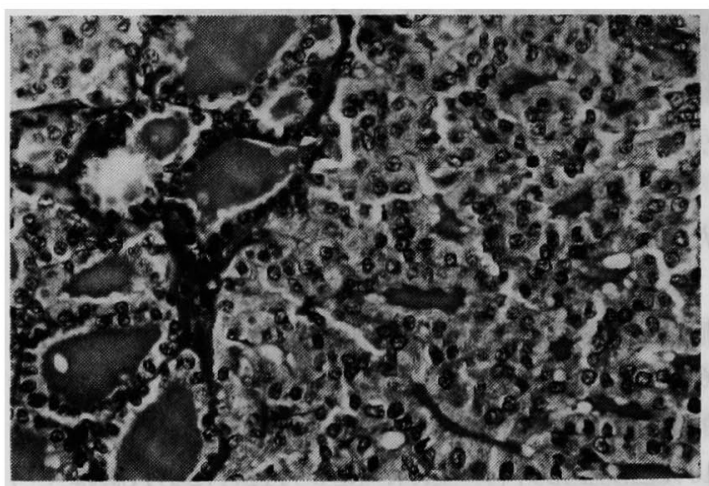

图 3 甲状腺原発栄の病理組城所見：㴧胞形成は存在 するが，一部索状ないし充実性の配列が認められる (HE 染色, $\times 400)$.

右葉上中部にあり，それと類似の性状の径 $2 \mathrm{~cm}$ 大の結 節が右葉下部と峡部に 1 個ずつ見られた。また，他に 腺腫様甲状腺腫と思われる0.5 1.5 cm 经の結節が 4 個左葉に存在した（図 2 ）。

病理組織所見：肉眼所見に一致して，多発性に腺内 転移を扢こした满胞癌（図３）が認められ，また腺腫 様甲状腺腫の所見が見られた。

術後経過：術後は特に合併症なく順調に経過し， 2 日目よりリオチロニンナトリウム $\left(\mathrm{T}_{3}\right) 75 \mu \mathrm{g} /$ 日を内服 し始め，10日目の 6 月21日に退院した。

${ }^{131}$ I 治療：甲状腺全摘後35日目の7月16日より ${ }^{131}$ I 治療目的にて，当院放射線科へ 1 週間入院, $T_{3}$ 経口服

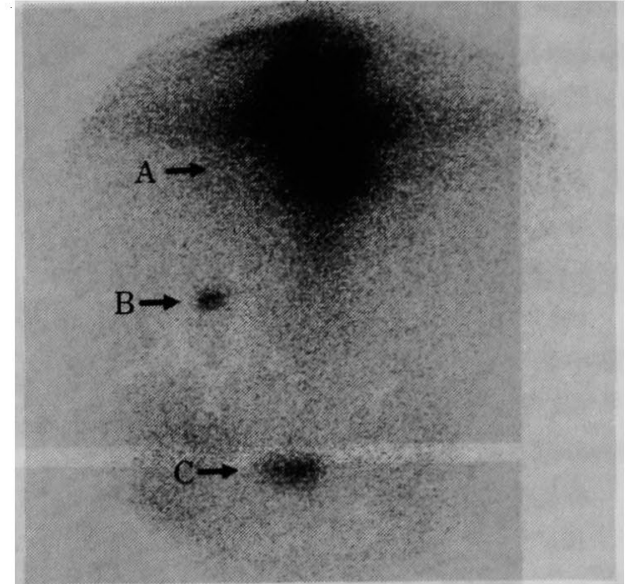

图 4 衍後 ${ }^{131}$ I シンチグラム：残存甲状腺 (A)，第 5 肋骨 (B)，第11胸椎 (C)に取り込みが認められる.

表 1 治㞠経過にともなう血清サイログロフリン值 の变款

\begin{tabular}{|c|c|c|c|}
\hline & & $\underset{(\mu \mathrm{U} / \mathrm{ml})}{\text { TSH }}$ & $\begin{array}{c}\text { 血清サイロ } \\
\text { グフリン } \\
\text { (ng/ml) }\end{array}$ \\
\hline 昭59.5.7 & 入完 & 1.1 & 5,500 \\
\hline 11 & 椎弓切除 & & \\
\hline 6.11 & 甲状腺全揞 & & \\
\hline 7.2 & $\mathrm{~T}_{\mathrm{s}}$ 威中止 & & \\
\hline 16 & 初回 ${ }^{191}$ 投与 $(78 \mathrm{mCi})$ & 66.1 & 4.180 \\
\hline 17 & & 40.2 & 2.980 \\
\hline 19 & & 61.8 & 4,090 \\
\hline 21 & & 57.2 & 3,300 \\
\hline 8.16 & & 1.0以下 & 2,212 \\
\hline 10.8 & $T_{3}$ 都中止 & & \\
\hline 22 & 第 2 回 ${ }^{131} \mathrm{I}$ 投与 $(156 \mathrm{mCi})$ & 99.1 & 4,648 \\
\hline 24 & & 80.7 & 2.916 \\
\hline 26 & & 116.8 & 2,932 \\
\hline 29 & & 154.5 & 3.068 \\
\hline 12.23 & & 1.2 & 950 \\
\hline 昭60.2.21 & & 1.0 & 3.652 \\
\hline 5.2 & & 1.0 & 8.950 \\
\hline
\end{tabular}

注：血清サイロダロブリン $(\mathrm{Tg})$ 值は，測定時 TSH 上昇に上り著明に上昇する。入院時(TSH1.1)に 比し初回 ${ }^{131}$ 投与時(TSH66)に Tg 值が低下し ているのは甲状腺全摘のため,さらに第 2 回 ${ }^{131}$ 治療後 $\mathrm{Tg}$ が著しく低下しているのは1 ${ }^{131}$ I治療 効果のためである。

用を 2 週間中止後に ${ }^{131} \mathrm{I} 78 \mathrm{mCi}$ を投与した。シンチタ ラムにて，残存甲状腺，気管前気管傍リンパ節と思わ れる部位，第11胸椎々体，および第 5 助骨に集積が認 められた(图 4 )。ささらに 3 力月後の10月22日より2遍 間放射線科入再入院し ${ }^{131} \mathrm{I} 156 \mathrm{mCi}$ の投与を受けた。血 
清サイログロブリン値は 2 回の ${ }^{131}$ I 㞠法施行後とすに 著明な低下を示した（表 1 ）。

患者は治㞠開始の 1 年後の昭和60年 5 月より再び腰 痛と軽い歩行障害が出現し，転移腫瘍は少し増大傾向 にある. 治療開始 2 年後の現在なお生存中で, 車椅子 にて通院，リハビリテーション中である.

\section{II. 考 案}

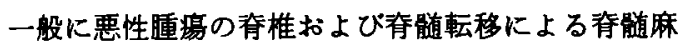
痷は，一旦その改候が現われると，その後急速に進行 することが多く，その対処は緊急を要する. Onofrioは 6 カ月以上の生存が望める患者には，外科的減圧を行 なうことを勧めている゙1.この麻瘏の改善のため椎弓 切除を行なった報告はいくつかあるが，概ね $230 〜 60 \%$ に術前にあった麻疩症状の改善が得られている2)-5). 麻瘏の進行が遅く，かつ麻疸の程度が軽い患者程有効 である傾向がみられる゙い!。

甲状腺濾胞癌においては骨転移がしばしば見られ， 金椎骨転移も比較的高頻度に見られる。しかし，転移 性等䯣腫瘍全体でみると, 甲状腺癌由来のものの頻度 は2－6\%と低く20677，この意味においては比較的少 ない病態の 1 つと言える。

本邦において過去10年間，甲状腺癌等椎扣よび脊蹃 転移に対する椎弓切除などの減圧術を施行した報告は 9 例あり，5例に麻痷の改善が得られている23). 4 例 は報告時に死亡しているが，組織型，手術時期，他の 治療法について不明な症例も含まれているため，予後 に対する影㖕の検討はできない。

しかし，別府らの報告による脊噵麻疸に対して椎弓 切除を行なった悪性腫場の瓷椎・脊䯣転移例の, 平均 生存期間が8.3カ月であるのに対し2)，土屋の報告によ る骨転移を伴なった甲状腺滤胞癌患者の生存期間は半 年から13.4年と長い6). 甲状腺分化癌は腫掦の進展が 比較的緩徐なるのが多く，適応を選んで羊髄除圧手術 を行なえば，手術効果は期待でき，また全身的にも上 記の如く生存期間が他の悪性腫場例に比べれば長いの で, 椎弓切除などの減压法を積極的に試みることは十 分意義があると思われる。

近年血中サイクログロプリン濃度の湘定が可能とな $\eta^{8)}$, 甲状腺癌の患者に扎いて, 甲状腺全摘後の癌再 発，転移の早期発見に有用である象10). 本症例において
は，術前の血清サイログロプリン值は $5,550 \mathrm{ng} / \mathrm{ml}$ と 高度に上昇していた。 甲状腺全摘後 $\mathrm{T}_{3}$ 斉の投与中止 後，TSH が66.1 $\mu \mathrm{U} / \mathrm{ml}$ に上昇した時点での血清サイ ロクロプリンは4, $180 \mathrm{ng} / \mathrm{ml}$ と高値を示した，2回 の ${ }^{131}$ I治療後はいずれもサイログロブリン值は低下し た.このよ 5 に血清サイログロブリン值は, 腫瘍マー カーとして，治療効果判定の指標となりらる。

III. 結 語

今回経験した症例では，内分必外科医，整形外科医， 放射線科医か，相互に緊密な連絡をとり，集学的治療 を計画的かつ迅速に行ったことが好結果を招いたと思 われる。

\section{文献}

1) Onofrio, B.M.: Metastatic disease to the spine. Mayo Clin. Proc., 55 : 461-462, 1980.

2）別府保男, 福間久俊, 西川耕平他：悪性腫瘍荨椎㧍

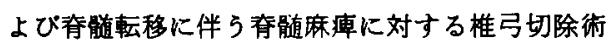
の検討, 癌と化療, $10: 171-179,1983$.

3) Hattori, A.: Laminectomy for spinal cord compression from metastatic tumor, 日外宝, $45:$ 175-180, 1976.

4) Shaw, M., Rose, J.E. and Paterson, A. : Metastatic extradural malignancy of the spine. Acta Neurochir, 52 : 113-120, 1980.

5) Rodriguez, M. and Dinapoli, R.P. : Spinal cord compression with special reference to metastatic epidural tumor. Mayo Clin. Proc., 55 : 442 $-448,1980$.

6）土屋敦雄, 渡辺岩雄, 星 竹敏他：甲状腺癌骨転移 に閔する臨床的検討, 癌の臨 $24: 1187-1190$, 1978.

7) Goldberg, L.D. and Ditchek, N.T.: Thyroid carcinoma with spinal cord compression. J.A. M.A., 245 : 953-954, 1981.

8）藤本吉秀: 甲状腺癌診療の進步, ホルモンと臨, $32: 721-726,1984$.

9）藤本吉秀：甲状腺腫場の診断と治療，ホルモンと 㯺, 32:433-437, 1984.

10）小原孝男, 藤本吉秀 : 甲状腺悪性腫痬, ホルモンと 臨, $32: 61-72,1984$. 


\title{
ORTHOPEDIC, SURGICAL AND RADIONUCLEIC COOPERATIVE TREATMENT \\ OF FOLLICULAR CARCINOMA OF THE THYROID WITH SPINAL CORD COMPRESSION -A CASE REPORT-
}

\author{
Hisato HARA, Tohru YASHIRO, Tomoyuki YAMASHITA, Yoshihide FUJIMOTO, \\ Kiyoko KUSAKABE, Hiroshi TAGAWA and Akira HIRAYAMA \\ Departments of Endocrine Surgery, Radiology, Orthopedics and Surgical Pathology, \\ Tokyo Women's Medical College, Tokyo, Japan
}

A 51-year-old woman was admitted because of a thyroid tumor and development of paralysis of the lower half of the body. Physical examination and a 201Tl-chloride whole-body scan disclosed a metastatic lesion in the 11th thoracic vertebra. Four days after admission, the patient underwent a laminectomy which relieved the symptoms of lower-half paralysis. One month later, a total thyroidectomy was carried out and after one further month, radioiodine treatment was carried out. The spinal lesion decreased in size after two sessions of 131I treatment and the serum thyroglobulin level markedly decreased from $5,500 \mathrm{ng} / \mathrm{ml}$ to $950 \mathrm{ng} / \mathrm{ml}$. 